\title{
The Study of Arundhati Roy's The God of Small Things: History, Diaspora, Hybridity, Women
}

\author{
Shiva Zaheri Birgani1, *, Sayyed Rahim Moosavinia ${ }^{2}$ \\ ${ }^{1}$ Department of English Language and Literature, Boroujerd Branch, Islamic Azad University, Boroujerd, Iran \\ ${ }^{2}$ Shahid Chamran University of Ahvaz, Ahvaz, Iran \\ Email address: \\ shvzaheri@gmail.com (S. Z. Birgani) \\ ${ }^{*}$ Corresponding author \\ To cite this article: \\ Shiva Zaheri Birgani, Sayyed Rahim Moosavinia. The Study of Arundhati Roy's The God of Small Things: History, Diaspora, Hybridity, \\ Women. Arabic Language, Literature \& Culture. Vol. 4, No. 1, 2019, pp. 21-31. doi: 10.11648/j.allc.20190401.13
}

Received: April 3, 2019; Accepted: June 3, 2019; Published: June 17, 2019

\begin{abstract}
From the fifteenth century to the twentieth century, the Europeans colonized the lands in other continents. In the nineteenth century, the main political purpose promoted the newly-born genre named 'novel'. In developing the dominance of colonization, writers played a main role. Knowledge and power are the dominating themes that over-rule the deep nature of imperialism and literature. These themes indicate the superior literature, culture and tradition as the standard form of acceptance. Colonization is a period of time. This is history itself. In the result of the colonization, the migration and transition were not avoidable issues. Therefore, in this displacement, the new identity has been made. People's customs, cultures and beliefs are mixed with colonizers' unconsciously. India is a multicultural country. There are many various cultures in this country. And also during the colonization and the dominance of Britain over India, the changes were made in its customs and cultures. Arundhati Roy is an Indian writer and female activist. The plot of Roy's novel is made from the ancient history of the Syrian-Christian community and the complex intermixture of their faith with local Hindu social structures. In such society, people married other people with different beliefs. The present research intends to analyze the mentioned novel based on postcolonial studies. The concepts that can be mentioned in this novel are history, diaspora, hybridity, the role of women in Indian society, globalization, and resistance.
\end{abstract}

Keywords: Post Colonialism, Resistance, Diaspora, Hybridity, Orientalism

\section{Introduction}

Colonialism is maintaining of colonies in one territory by the people from another territory. Colonizers change the structure, government, and economics of the colony. It is a period of history from the late fifteenth century to the twentieth century when the Europeans established colonies on other continents. Postcolonialism is a period of time after colonialism. Postcolonial literature refers to any literature that expresses an opposition to colonialism, even if it were produced during a colonial period. It often records racism or a history of genocide, including slavery, apartheid, and the mass extinction of peoples. The nature and subject of most postcolonial writing are very different geographical, historical, social, religious, and economic concerns of different ex-colonies.
Many postcolonial writers believe that their countries are still very much colonial countries, both in terms of their values and behaviors. African countries, Australia, Canada, India, New Zealand and South Pacific countries all have postcolonial literature. Literatures of all countries express real experiences and observations of colonization. Each of them has its own special and distinctive regional characteristics. Significant critics in the field of postcolonial literature are, Homi Bhabha, GayatriSpivak and Edward Said. The authority of the West over the colonized countries biased the representations of 'Other' cultures in Western literature. Few writers have broken the boundaries and limitations of Eurocentric literary standards in order to recall the true nature of imperialistic nature in these countries. Literature mirrors the cultural and social attitude of its author. This matter highlights literary criticism as means of understanding these texts. India was one of the countries 
colonized by Britain. TGST shows a historical and political period in the late of 1960s in India. History is an important and significant concept in postcolonial literature. Migration and diaspora take place in the historical context. These two elements create a new identity. This is named hybridity that it refers to transcultural rather than multicultural. Therefore, hybridity is important in the colonized regions.

\section{Method}

The present researcher tries to discuss the history of colonialism, post colonialism, the relationship between the role of women and postcolonial literature, Saidian Orientalism, diaspora and hybridity in this paper.

Colonization has played an important role during the history of human life. Colonization refers to the domination of a group of people over people's land and goods. Colonialism refers to the domination of various European powers into other land in the world and it refers to a feature of human history. This notion rests during the history of human life. The colonial rulers affected the lives of the colonized population. These rulers believed that they have superiority and ordained mandate to rule over colonized population. The colonies were full of labour and human resources.

The present researcher tries to analyze the novel based on some postcolonial concepts. Hybridity is based on White who believes that history is the title of scientific discipline in the nineteenth century. In postcolonial regions, there is migration and transition of the different nations always. In the result of this transition of the peoples, the new identities had been made .This condition creates transcultural identity. Hybridity became significant concept in postcolonial studies. The present researcher tries to work on diaspora and hybridity from Bhabha's view. The writer and the character of Ammu are women. And they belong to diasporic community, the researcher wants to work on the role of women in Indian society. Other concepts are resistance and orientalism. Said worked on the two last concepts. The process of the world shrinking and becoming a single place refers to globalization. This happens in complex society. India tries to inject foreign investment for globalization.

Colonization has important role during the history of human life. British Empire colonized India at the end of the sixteenth century. This land has important benefit for Britain. This colonization affected Indian society, culture, and literature. Therefore, the researcher tries to discuss the history of colonization, colonization in India and the effect of colonization in Indian culture, and literature.

Another issue is discussed is postcolonial theory. Postcolonialism is a state after the formal end of colonialism. The aspects of postcolonialism may be in history, literature and politics. Postcolonialism affected both the countries that were colonized and the former colonial powers. Women had important role in postcolonial theory. Because the family becomes the symbol of anti-colonial movement and it indicates inner space in colonialism.
Edward Said is an American-Palestinian theorisian believes that Western culture has a kind of view about the Eastern cultures. It is called Orientalism. Said discusses about this matter in his book, Orientalism. Diaspora is another basic concept in postcolonial study which Bhabha works on it. Diaspora refers to the movement of a group of the people from a land to another land. There are many races in the world. These races have different cultures and ideas. Hybridity is created by mixing two races. The concept of hybridity is central term to postcolonial theory.

\subsection{The History of Colonialism}

According to Loomba, in her book Colonialism/ Postcolonialism, colonialism is "the domination of a group of people over other people's land and goods" (8). In this debate, "colonialism" refers to the domination of various European powers into other land in the world and it refers to "a feature of human history". Colonialism refers "to exploitation of labour and interference with political and cultural structures of another territory or nation, and imperialism as a global system" [1].

There is colonialism in different periods of history; such as Roman Empire from Armenia to the Atlantic in the second century AD. Moreover, "the Mongols" dominated "the Middle East" as well as "China" in the thirteenth century. Colonialism essentially refers to a period of history from the late fifteenth century to the twentieth century. In this period, European nation states established their colonies on other continents. The British Empire, French colonial empire and the Dutch Empire were produced in the seventeenth century. Moreover, some Swedish colonies and a Danish colonial empire were established. When the American Revolutionary war and the Latin America wars of independence were happened in the late eighteenth and early nineteenth centuries, the spread of colonial empires was reduced. In the late nineteenth century, many European powers were involved in the Scramble for Africa.

The colonizers have several reasons for this action such as accessing raw materials for producing their industrial products, finding target bazaar for selling their industrial products, expanding the power of the metropole, escaping persecution in the metropole, and spreading their way of life, culture, technology, religious and political beliefs. The colonial rulers affected the lives of the colonized population. They believed that they have superiority and ordained mandate to rule over colonized population.

There was a complex relationship between colonized and colonial countries. Human and natural resources were colonized by the colonizers. The colonizers transported slaves and raw materials to the metropolis, the colonies also became captive markets for European goods. In West India, Indians produced sugar for Europeans; Indians moved raw cotton to be manufactured into cloth in England and then was sold back to India. European colonialism applied different techniques and patterns of the domination, they moreover penetrated deep into some societies. All societies produced the economic imbalance that was necessary for the growth of 
European capitalism and industry. Thus colonialism produced European capitalism. "The colonies" did not have capital but were "full of labour and human resources" [1].

British Empire included several colonized lands through the world such as India, America, Canada, and Australia. Englishmen were as representatives of Elizabeth I or James I. They acted in the base of English customs in merchants, traders, financiers as well as feudal lords. India was one of Britain's Asian colonies. The present researcher will discuss India in a later part.

\subsection{Colonization in India}

At the end of the sixteenth century, England and the United Netherlands began to challenge Portugal's monopoly of trade with Asia, forming private joint-stock companies to finance the voyages - the English, later British, and the Dutch East India Companies, which were chartered in 1600 and 1602 respectively. The primary aim of these companies was to tap into the lucrative spice trade, and they focused their efforts on the areas of production, the Indonesian archipelago and especially the Spice Islands, and on India as an important market for the trade. The close proximity of London and Amsterdam across the North Sea, and the intense rivalry between England and the Netherlands, inevitably led to conflict between the two companies, with the Dutch gaining the upper hand in the Moluccas (previously a Portuguese stronghold) after the withdrawal of the English in 1622, but with the English enjoying more success in India, at Surat, after the establishment of a factory in 1613 .

The British had direct or indirect control over all of present-day India before the middle of the nineteenth century. In 1857, a local rebellion by an army of sepoys escalated into the Rebellion of 1857 , which took six months to suppress with heavy loss of life on both sides. This resistance, although short-lived, was triggered by British attempts to Westernize India. As a result, the East India Company lost its powers of government and British India formally came under direct British rule, with an appointed governor-general administering India. The East India Company was dissolved the following year in 1858. A few years later, Queen Victoria took the title of Empress of India.

India suffered a series of serious crop failures in the late nineteenth century, leading to widespread famines in which at least 10 million people died. The East India Company had failed to implement any coordinated policy to deal with the famines during its period of rule. This changed during the Raj, in which commissions were set up after each famine to investigate the causes and implement new policies, which took until the early 1900 s to have an effect.

The slow but momentous reform movement developed gradually into the Indian Independence Movement. During the years of World War I, the hitherto bourgeois home-rule movement was transformed into a popular mass movement by Mahatma Gandhi, a pacifist. Apart from Gandhi, other revolutionaries such as Shaheed Bhagat Singh, Chandrashekar Azad and Subhash Chandra Bose, were not against the use of violence to oppose the British rule. The independence movement attained its objective with the independence of Pakistan and India on 14 August and 15 August 1947 respectively. Some conservatives in England consider the independence of India to be the moment that the British Empire ceased to be a world power.

\subsection{Saidian Orientalism}

Edward Said is a literary and cultural theorist. He was born in Jerusalem, Palestine. He was educated in Jerusalem, Cairo, Massachusetts. He received his BA from Princeton in 1960 and his $\mathrm{PhD}$ from Harvard in 1964. He was Parr Professor of English and Comparative Literature at Columbia University. Also he was a professor at "Harvard, Stanford, Johns Hopkins, and Yale" [2].

Said adapted his idea about the cultural position and task of the intellectual and literary critic from "Foucault" (ibid). He worked about historical production and motivations of Western discourses about the Orient in general and about Islam in particular. Also he paid attention to the Palestinian struggle to regain their homeland. He wrote several books such as; Beginnings, Orientalism, The Question of Palestine, Covering Islam, The World, the Text, the Critic, Culture and Imperialism [2]. The present researcher tries to use two of his works, Orientalism and Culture and Imperialism. In Orientalism Said tells us the tradition of Western "construction" of the Orient (ibid). He introduces a binary opposition between West and Orient. He tells West constructs Orient. He believes that "Orient is a production of Western discourse" [2]. And "it is indeed a language, with an internal consistency, motivation, and capacity for representation resting on a relationship of power and hegemony over the Orient" [2]. Culture and Imperialism "is a continuation of the themes raised in Orientalism" [2]

Leela Gandhi, in her book Postcolonial Theory, believes that "Said elaborates the principal features of postcolonialism's intellectual inheritance" (64). This book is as a postcolonial classic and also it has academic influence and theoretical "Orientalism" is as "the reference point for postcolonialism". It represents "the first phase of postcolonial theory, It regards discursive and textual production of colonial meaning and "the stabilization of colonial authority" [2].

There is a dichotomy between Europe and its others It refers to representations of the "Orient" in European literary texts, travelogues and other writings [3]. Said believes that the Europeans gained "knowledge" about "non-Europeans" and then they used it to maintain power over them. Thus the lines between the ideological and the objective darkened. Said sustains "Europeans individually do not like nonWestern peoples or cultures" [3]. Said, in his book Orientalism, points out that:

a political vision of reality whose structure promoted the difference between the familiar (Europe, the West, 'us') and the strange (the Orient, the East, 'them') [...] When one uses categories like Oriental and Western as both the starting and the end points of analysis, research, public policy [...] the result is usually to polarize the distinction- the Oriental 
becomes more Oriental, the Westerner more Western- and limit the human encounter between different cultures, traditions, and societies. (45-6)

Loomba, in her book Colonialism/Postcolonialism, says that Said uses of "culture and knowledge to investigate colonial power originate colonial discourse studies" (44). Discourse analysis traces connections between the dominant and the marginalized, ideas and institutions, the visible and the hidden. What is discussed id how power works through language, literature, culture. Saidean Orientalism is the "study" of the Orient which was "a political vision of reality whose structure" elevated a binary opposition "between the familiar (Europe, the West, 'us') and the unfamiliar (the Orient, the East, 'them') [3].

There is a dialectic between self and other. It is derived from deconstruction. This dialectic is effective in following studies of colonial discourse in other places. It refers to these conception, if colonized people are irrational, Europeans are rational; if the former are barbaric, sensual, and lazy, Europe is civilization itself; if the Orient is static, Europe is developing and dynamic; if "the Orient is feminine, Europe is masculine" [3]. Orientalism studies includes analyzing a wide range of cultural texts such as art works. "Cinema, scientific systems, museums, educational institutions, even patterns of clothing" [3].

Orientalism sustains that a binary opposition between East and West has been a more or less static feature of Western discourses from classical Greece. Said wants to promote the importance of literary, ideological and discursive aspects at the charge of more institutional or material realities. Colonialism was an ideological production. Said analyzes standard Western literary texts. Said focuses on the imposition of colonial power rather than on the resistance to it. It is the same self-representation. "The colonizer possessed colonial power and discourse, and there is no possible for change" [3].

The nature of colonial power is a feature for postcolonial studies. Orientalism suggests that Western texts create not only knowledge about the Orient but the very reality they appear and imply that the historical experiences of colonial peoples themselves have to independent outside the texts of Orientalism. Said appears to have placed himself in the position of denying "the possibility of any alternative description of the Orient, any alternative forms of knowledge and by extension, any agency on the part of the colonized. ... since even he seems trapped within the frame of Orientalism, unable to move outside it" [3].

Orientalism focuses how the Orient was "constructed" by "Western literature", "travel writing and systems of studying the East", not how it toke apart by colonial subjects [3]. Said believes that colonist's discourse is all general (universal). Said sustains Orientalism thought can be challenged.

Joel Kourtti and Jopi Nyma, in his book Reconstructing Hybridity, states that "Said defines the Orientalist as a Western person who establishes an authority in the texts of colonized peoples" (6o). "Black" refers to "the non-Christian races in Christian term". These persons are primitive and non-civilized. We can use "Said's Orientalism to conceptualize this different". Orientalism is a technology of thought which provided "a mechanism of othering in terms of knowledge of its subject". This "Other" provided "a difference, the arbitrary sign of the color of skin" (66).

Gandhi, in her book Postcolonial Theory, maintains that both "the West and the postcolonial non-West" are affected by Orientalism in "intellectual formations, structures and lives" (66). "Orientalism" shows the historically imbalanced relationship between "the world of Islam", "the Middle East", and the "Orient" on the one hand, and that of "European" and "American imperialism" on the other.

\subsection{Diaspora and Hybridity from Homi Bhabha's View}

Human beings are essentially different. There are many races in the world. Different races have different cultures and ideas. The colonizers tried to establish stable and fixed identities in their colonized. Several critics like Homi Bhabha suggests that these struggles face the failure of colonial regimes. Racial stereotyping refers to the Greek and Roman periods. Moreover, it existed in medieval and early modern Europe. Although in the base of the Bible, all human beings were brothers and had the same parents, the "savages" and "monsters" was not easy to explain [3]. There is one reply that these creatures cause God's wrath. In other side, the blackness like "Ham" (Noah's bad son) were mentioned in "the Bible". Although various European nations had the different colonial enterprises, they generated similar stereotypes of "outsiders". These outsiders included those outsiders who were the edges of the world, and those who stereotypes of outsiders. These outsiders included those who outsiders the edges of the world, and those who (like the Irish were nearer home). It means that the colony is colony: There is no difference between each colony and outsiders. "The colonizers, English, French, Dutch, Spanish, Portuguese colonists attributed some attributions such as laziness, greed, violence, primitivism to Turks, Africans, Native Americans, Jews, Indians, the Irish, and others".

In addition, Loomba mentions that "colonizers interacted with local populations in different modes". Their modes produced variable racial discourses and identities. For example, "the Spanish accepted local manners and intermarried in America, but the English derided them". Such inter-marriages and concubinage blurred racial distinctions. "Sexual contact, Spanish and Indian, makes the hybrid population and encode a complex grading system of color, class and gender in Latin America". Social or "sexual contact" with local peoples was "false for British colonialism" (97). In India, this policy reveals the nature of colonial administration. Thus this often merged rather disorganized native hierarchies. "Millions of Indians never saw an English person throughout the term of the Raj, although that did not mean their lives had not been woven into the fabric of empire". This kind of "shallow penetration" can be seen as "a prototype for modern imperialism", which functions largely through remote control. But there was another pattern in other countries like South Africa. 
According to that pattern, "colonizer maintained racial division with direct and powerful intervention". Sometimes heterogenetic, variety and diversity indicate lack of purpose or ideology. "The British Empire, never really possessed an ideology — was temperamentally opposed, indeed, to political rules, theories and generalizations". It was the most important political organism of its time, yet it was seldom altogether sure of itself or its cause. Colonialism had "several ideologies", not one. Their several ideologies reflected "in hundreds of different institutional and cultural practices". They all fed into a global imbalance.

The colonizers try "to convert native's religion for economic plunder". Turks, Moroccans, Indians and others accepted Christianity. These conversions showed in sixteenth and seventeenth-century plays, travelogues and pamphlets. For example; Thomas Middleton was the well-Known dramatist. He wrote The Triumphs of Honour and Virtue for the Lord Mayor of London's initial (opening) ceremonies in 1622. "An Indian Queen converted her religion to Christianity". "Colonizers expanded missionary actives", but did European fears of contamination (100).

There are "three points about scientific theories of race". Firstly, there is the "contradiction between racial difference and the Biblical notion for human species as a unitary creation of God" (101). Many scientists suggest that environmental factors had changed the original species. If "race" is interpreted as "species", there is no possibility for "inter-mixing between races, and the unavoidable disintegration of racial difference". But there is the mixed population of the West Indies and the United States. And there was one response to this matter that intermixtures between races "led to declining fertility". Another was that racial difference referred variety within a single species, not different species. Secondly, if racial characteristics were ascribed to "biological differences such as skull and brain sizes", and these factors were connected and cultural issues, "science turned savagely and civilization into fixed and permanent conditions". This fixity is contradiction to the imperial claim of civilizing the natives. It means that "if savagery is a biological condition, then civilizing the natives has on meaning". "Thirdly, science expanded the association of race and nation" (102). From the eighteenth century scientific racism was classified that race refers to cultural formation and historical development. "Nations" are often considered as "the expression for biological and racial attributes". Skin colour is the prime marker of racial identity. Then it is investigated by perceptions of religious, ethnic, linguistic, national, sexual, and class differences. "Race" is a concept which is "in relation to other sexual groupings and hierarchies, such as gender and class" (105). Hybridity is a central term in postcolonial theory. It refers to impurity and mixing between human races. 'Hybridization' is an aspect of colonial contacts in everywhere. Particular historical contexts and other social hierarchies shaped racial constructions.

There are some issues in postcolonial studies such as diasporas, mobility and cross-overs of identities, hybridity, creolization, with the in-betweenness. A hybrid is technically a cross between two different species. "Colonialism needs both to civilize its others and to fix them into perpetual otherness" (105).

Today heterogeneity, cultural interchange and diversity have become the self-consciousness identity of modern society. There are the historical and fundamental links between language and sex. J. C Robert Young, in his book Colonial Desire and the word "hybrid" has derived from biological and botanical origins: it is "the offspring of human parents of different races" (4). Hybrid is the nineteenth century's word. In this century it was used to refer to "a physiological phenomenon"; in "the twentieth century" it has been reactivated to describe "a cultural one" (5). Between 1843 and 1861, there could be such a thing as a human hybrid. In the nineteenth century and the twentieth century, "hybrid was a key issue for cultural debate" (6). The idea of human being of different species conflicts with "the Biblical account"; the emphasis was very much on "all humans belonging to a single family" (7).

\section{Literature of Review}

British Empire colonized lands through the world such as India, America, Canada, and Australia. British Empire colonized India at the end of the sixteenth century. This land has important benefit for Britain. Literature creates new genres, ideas and identities. Writers Such as John Donne have used colonialist concerns in their writings. John Donne writes about the lovers' private space in terms of the fast expanding outer world in his poems. Donne describes the female body in terms of the new geography in his "Love's Progress" Donne resembles sexual relationships to colonial relationships. He believed that a male lover, like a European discoverer, who discovers other lands, discovers the female body. And the sexual promise of the female body is like the colonies' wealth. Said's Orientalism expresses "literature as a part of the creation of colonial authority". Loomba, in her book Colonialism/Postcolonialim, maintains Literary texts can oppose dominant ideologies (67). Moreover, literature both reflects and creates modes of expression that are central to the colonial process. Plays such as Othello and The Tempest focus on colonialist ways of seeing and have inspired anti-colonial and anti-racist movements and literature. There are cross-cultural interactions and hybridities in literature. There are the Europeans and their reading of non-European texts and traditions, especially Arabic texts, throughout the medieval and early modern periods. Literary texts help us towards "an analysis of colonial history". Literary texts can oppose dominant ideologies. Moreover, many of English novels were written about India during the British colonization. In the nineteenth century, British literature represented that imperialism was an important part of the cultural representation of England to the English. Another aspect of the relation between literature and colonialism refers to dominant critical views, which sanctified within educational systems. Britain changed literary studies to a discipline of study in British universities 
for colonial administrators instructed in Western literature. Colonialism and literature are interconnected with each other.

\section{Discussion}

Post colonialism is a subject of debate in contemporary literary and critical studies. This is a state after the formal end of colonialism. Its origin is in the West. It depends on Western philosophy labeled as the Euro-centric. It is a complex phenomenon that is embodied with excessive jargon and branded as the latest catchall term to dazzle the academic mind. The postcolonial Indian English fiction reflects the spirit of different regional literature as a whole. The concept of nation became a curious debate in the postcolonial study. The postcolonial Indian English fiction witnesses at least three generations of Indian novelists in English. Arundhati Roy belongs to the third generation. She established the frame in international arena. Indian English fiction succeeded to win almost every well-known literary prize in the world. In colonialism, the family becomes the symbol of anticolonial movement because it indicates inner space. The family will be the symbol of resistance. The repressed peoples make anti-colonial nationalism to represent a selfhood during colonial rule. The image of nation as a mother indicates both female power and female helplessness. This mother defends her son against colonial pillages, but it is also herself devastated by colonialism and she needs her son's protection. In Indian culture, the ideal woman is drawn by "brahminical notions of female self-sacrifice and devotion" [4]. In Indian society, women's fighting confronted strong political interaction. Gandhi ignored women's fighting, and followed the conceptions of the family and society. Many women were active in colonial struggles. They were not feminist; they did not see tension between their own struggles and those of their community at large. They went into public spaces in the name of motherhood and family. Women continued their struggle for equality after formal independence and described the nature of postcoloniality. Postcolonial countries more easily admit women's participation in politics than metropolitan ones because of this nationalist legacy. The Hindu, Islamic or Christian rightwing movements are taken place by active women in different parts of the world.

The relationship between women, nation and community is variable, both in the colonial period and afterwards. Women try to struggle for self-determination, democracy, antiimperialism and re-shaped their understanding of themselves. Totally, postcolonial women's have fought "against state repression rape, racism, patriarchy, or better working conditions" (191). Postcolonial women's movements follow their local and native roots. They re-wrote local histories, pre-colonial symbols and mythologies, and expressed their voice. The role of women is bold in Indian society. Therefore, Roy uses several female characters, such as Ammu, Rahel, and so on in TGST. Today, these movements have to debate the dynamics of globalization, and the postcolonial nation-state. "Globalization often reproduces the general effects of colonialism" [4]. Globalization makes an international women's development network. "The governmental or feminist organizations" try to improve "women's health", or "working conditions", also moving "enlightenment from the West to the rest of the world" [5]. In postcolonial communities, women have attended in the full range of postcolonial politics, "from the more established forms of political action to the social movement" such as, environmental programmers [5].

Edward Said, an American-Palestinian theorist, elaborates on the principal features of postcolonialism's intellectual inheritance in his book, Orientalism. This book was published in 1978, as a postcolonial classic with academic influence and a reference point for postcolonial studies. This shows the first phase of postcolonial theory. This is a dialectic between self and other. This dialectic refers to these conceptions, if the former are barbaric, sensual and lazy, Europe is civilization itself; if the Orient is static, Europe is masculine. Orientalism studies include analyzing a wide range of cultural texts such as art works, cinema, scientific systems, museums, educational institutions, even patterns of clothing [6]. Orientalism shows a binary opposition between East and West. Said believes that the Orient was "constructed" by "Western literature", "travel writing and systems of studying the East", not how it taken apart by colonial subjects [6]. Said believes that Western culture has a kind of view about the Eastern cultures. It is called Orientalism. He argues that Western culture has romanticized images of Asia and the Middle East. This image is not based on reality and fact. The Western society believes that all Eastern societies are dissimilar to Western societies. Like Foucault, Said argues that there is "the relationship between power and knowledge in thinking" [7]. In particular European views of the Islamic Arab world. He discusses Middle Eastern, African and Asian history and culture. He postulated that Orientalism is "a modern political and intellectual culture" (12).

Said in "The Scope of Orientalism", argues that all cultures have a view of other cultures that may be exotic and harmless to some extent (33). The present research intends to show that there is the same view in TGST, when it is expressed that Velutha belongs to pulayas and the untouchable group of caste system. The word 'Untouchable' is repeated several times in TGST. For example this sentence could be considered: "He had been educated by her family, in the Untouchables' school started by her father, PunnyanKunju [8]. This group is placed in the bottom of the caste system. Velutha is pulayas from the higher class' view. And this caste system was constructed by the other (especially higher) people in Indian society. In TGST, Ammu is as a touchable who does not obey the orders of caste system, and she has relationship with Velutha as an untouchable. She does not obey hierarchy of touchable. It shows touchable/ untouchable and order/disorder. The phrases of "An unmixable mix" [9], and "Unsafe edge" refer to this order. She lives "in the penumbral shadows between two worlds, just beyond the grasp of their power" (123). This 
sentence shows two worlds of touchable and untouchable. In chapter 2, "Orientalist Structures and Restructures", Said suggests that "the East is a place of pure human culture with no necessary evil in the society" [9]. And "the Europeans believe that they needed the Europeans to assist them" [9]. One could say that the program of education for Indians continues this belief. And this can be seen in TGST, when Chacko is influenced by British culture and he is an Anglophile. He was educated in England. Another matter discussed in this chapter is Darwin's theories. According to this theory, there is the scientific division of races into "advanced and backward, or European-Aryan and OrientalAfrican" (207). Europeans adapted their belief from this theory. And they believe that they are superior biologically. When Roy writes "It was about nine in the morning when Mammachi and Baby Kochamma got news of a white child's body found floating downriver where the Meenachal broadens as it approaches the backward" [10], she points to being white and being English, and she does not mention Mol's half-Indian identity. The Indians know her as a British girl. This implies that it may refer to this theory. It may show that the Indians accept the belief that Europeans are superior to other races.

Suzanna Arundhati Roy is one of the best-known Indian woman writers. Roy was born in November 24, 1961. She is a novelist, essayist, activist who was born in Shillong, Meghalaya, India, to Ranjit Roy, a Bengali Hindu tea planter and Mary Roy, a MalayaliSyrian Christian women's rights activist. Her parents divorced and she lived with her mother. She spent her childhood in Aymanam in Kerala, and went to school at Corpus Christi, Kottayam, followed by the Lawrence School, Lovedale, in Nilgiris, Tamil Nadu. TGSTwas completedin 1996. The publication of TGST catapulted Roy to instant international fame. It received the 1997 Booker Prize for Fiction and was listed as one of the New York Times Notable Books of the Year for 1997. She is the first Indian woman to win the Booker Prize in 1997. TGST covers a broad historical spectrum: pre-colonial; British colonial; Postcolonial; Hindu, Christian and Communist. In Roy's TGST (2007), Tickell states:

Postcolonialism is a more influential perspective. Postcolonialism involves a range of the economic, cultural and ideological experience of European colonialism and its historical legacy. These features were shown in the writings of colonized countries. India is one of these countries. The Indians apply the English language to articulate their own identities after, and in opposition to colonial rule. In the novel Indian situations and characters are models for postcolonial outlook. (72)

The novel takes place in Ayemenem, a village in the southwestern India state of Kerala, in 1969 and 1993. India is a very complex society with various cultural and religious habits and beliefs. Hindus, Buddhists, Christians and Muslims share the same space Society and is divided not only by the very strict caste system but also by class consciousness. There are a number of languages spoken in India, but the higher classes make a point of speaking
English, sending their sons to study in England and adopting certain English habits. Kerala is a small India. This is a complex society too. It has a complex social setup with Hindus, Muslims and Christians having lifestyle, habits, beliefs and traditions different from each other. It also has the largest number of Christian population compared to other parts of India, predominantly Saint Thomas Christians or Syrian Christians. Kottayam is a district where the Christians are a majority. In more modern history, Kerala achieved statehood in 1956 after existing as part of the TravancoreCochin region since India's independence in 1947. Kerala's official language is Malayalam, although it is not uncommon for inhabitants to be familiar with several other languages from neighboring territories. Inhabitants have included Portuguese, Dutch, British, rulers from all over India, and religious groups escaping persecution in their own countries. Kerala is lauded for its outstanding progress in the areas of cleanliness, education, and quality of life. The tourism board of Kerala boasts that it is not only India's cleanest state but also has a literacy rate above ninety percent and the highest physical quality of life in India.

History is a significant feature in the postcolonial works. According to Ashcroft et al, in Postcolonial Studies Reader, White believes that history seeks "the title of scientific discipline in the nineteenth century mould" (17). There are various layers of history in TGST such as, the history of Syrian-Christian in South India, the history of the caste system in Hinduism, Velutha as the Hindu God, Krishna, kathakali dance; an ancient and local dance in Kerala, Communism Party in Kerala, Naxalites in Kerala. Communism was so much more successful in Kerala. Because according to Communism, the people must be equal to each other. So the lower class follows it in Kerala. There are some special and capital words in TGST such as, Big God, Small God, Small Things, History House, Ayemenem House, and God of Loss. These words refer to historical events in Kerala. In Kerala, the ancient and social religious tradition that produced the Hindu caste system refuses to give way to the new, postcolonial present which sees a Communist Kerala heralding new economic opportunities. Kerala is a place at once spiritual and secular. It is a place where Communists have been elected to power since 1957 and are subsequently in government until this present day. Communism Party was successful in Kerala. Chacko had no really complete explanation for why the Communist Party was so much more successful in Kerala than it had been almost anywhere else in India, except perhaps in Bengal. In 1969 , the caste system functioned very strongly; it is the time of increased awareness around the world and peak of communist ideology. Society is divided by the very strict caste system and class consciousness. According to Communism, the people must be equal to each other. Thus Communism was more successful and it had followers in this region. For Roy, Kerala is a place where communism betrays common people and the god that presides is 'small god' limited and dissipated by the prevailing society. The novel, by and large, deals with dominant themes such as the caste 
issue, social norms and communist politics in Kerala.

Indian history and politics shape the plot and meaning of $T G S T$ in a variety of ways. Some of Roy's commentary is on surface, with jokes and snippets of wisdom about political realities in India. However, the novel also examines the historical roots of these realities and develops profound insights into the ways in which human desperation and desire emerge from the confines of a firmly entrenched caste society. Roy reveals a complex and longstanding class conflict in the state of Kerala, India, and she comments on its various competing forces. For example, Roy's novel attacks the brutal, entrenched, and systematic oppression at work in Kerala, exemplified by figures of power such as Inspector Thomas Mathew. Roy is also highly critical of the hypocrisy and ruthlessness of the conventional, traditional moral code of Pappachi and Mammachi. On the opposite side of the politicalfence, the Kerala Communist Party, at least the faction represented by Comrade Pillai, is revealed to be much more concerned with personal ambition than with any notions of social justice. The caste system is along with an economic class struggle. The Ipes are considered upper class. They are factory owners, the dominating class. Mammachi and Baby Kochamma would not deign to mix with those of a lower class. Even Kochu Maria, who has been with them for years, will always be a servant of a lower class. The main events of the novel are traced back through the complex history of their causes, and memories are revealed as they relate to each other thematically and as they might appear in Rahel's mind. Roy also employs a disjointed, nonsequential narrative that echoes the process of memory, especially the resurfacing of a previously suppressed, painful memory. Roy's assertions throughout the novel imply that the caste system still greatly affects present-day Indian society. A highcaste male with British education such as Chacko, and the caste system which made by mythological ideas are able to be kept intact through the various layers of history. The Anglophile Chacko who makes this insightful statement about Indian history: "our minds have been invaded by a war. A war that we have won and lost. The very worst sort of war. A war that captures dreams and re-dreams them. A war that has made us adore our conquerors and despise ourselves" (ibid 26). Chacko believes that the "war of dreams" is a war of histories [11]. It refers to a struggle of competing visions of Indian society. His notion of history presupposes it as a meta-narrative, where colonized persons would be denied a place in the grand historical narrative. Roy believed that history cannot be separated into clearly defined categories, problematic though that may be. And the caste system and sexual discrimination survive all political regimes and various layers of history: the "war of histories", that is, two layers of history: spiritual and secular and the Sanskrit mythological past and post-colonial present and their uneasy co-existence in present-day India. Roy refers to the "dreams that fueled the freedom struggle" [11].

There are some issues in postcolonial studies such as, diaspora, hybridity; in-betweenness, creolization, mobility and cross-overs identities. Hybridity is a central term in postcolonial theory. Hybridity refers to impurity and mixing between human races. Hybridization is an aspect of colonial contacts in everywhere. Colonialism needs both to civilize its others and to fix them into perpetual otherness. In the nineteenth century and the twentieth century, hybrid was a key issue for cultural debate. Homi Bhabha works on diaspora, and hybridity. Diaspora includes movement and tradition. "Diasporic identities" include those that "are formed through movement and the process of dispersal; they will never be able to return to their homes" [12]. They have constructed new kinds of cultural identity consciously. They have learned to live with other community and to speak from difference

As there are various layers and fragments of history in Kerala, and TGST takes place in this region. TGST is potential for Homi Bhabha's view. For this reason, this research uses his work, The Location of Culture. He introduces his influential terms such as mimicry and hybridity and linguistic ambiguity between colonizer and colonized in his work. Diasporic and hybrid identities can be made in the context of these historical events. Migration and diaspora are concerns of postcolonialism. Roy criticizes traditional forms of cultural practice, including patriarchal societies, or religious and ethnic groupings in her book with regard to feminism and nationalism. With regard to diasporic literature, a whole new set of questions arise. The diasporic writers we are looking at often describe very new problems and circumstances. They often talk about how enabling it can be for women to be in a different kind of community. This different kind of community can be the complex community of Kerala. Roy shows how the everyday is lived and is loaded with complexity. It shows how grand scale national politics cannot be understood without that micro-vision. The migration of Syrian Christians is significant migration in the novel. Roy refers to the history of Syrian Christian.

Diaspora is an important issue in TGST. Four migrations are pointed out in TGST. The first refers to Syrian-Christian community to Kerala. Kerala's population were Syrian Christians, who believed that they were descendants of the one hundred Brahmins whom Saint Thomas the Apostle converted to Christianity when he travelled east after Resurrection. The second refers to Chacko's migration to Britain. The third refers to Rahel's migration to America. The fourth refers to Father Mulligan's migration to India. He is an Irish priest who comes to Kerala for studying Hinduism. And finally he converts to Hinduism. It may constitute hybrid and diasporic identity in the result of these migrations. The character of Rahel, which is similar in many aspects to Arundhati's eventful life, deals, briefly, with the diasporic existence. Her TGST is semi-autobiographical and mixes her childhood experiences in Aymanam with a postcolonial scrutiny of history and relationships. Traditionally, the diaspora has been represented as a division, some kind of a loss, a draining, and eternal longing for what could be and was elsewhere, the home somewhere else, retained in the imagination, preserved like Arundhati Roy's famous pickling factory pickling exotic pickles. 
There are some issues of diasporic language in complex Indian society. We can see these diasporic issues in TGST. When the Moguls invaded Iran the Iranians converted them into ambassadors of the Iranian language. They made Persian or Parsi their court language in India. Parsi was the language of the court of many of the Indian kings till the British banned its use, after occupying India in the eighteenth century. Roy uses four diasporic words which are originated from Persian and then they come in English. We can see these words in the following sentences: when Roy writes "His family were once-wealthy zamindars who had migrated to Calcutta from East Bengal after partition" (19), she speaks about Ammu's husband. The word "zamindars" in this sentence shows diasporic feature in TGST. Roy writes "They did [...] caught in the bazaar - branded them so that everybody would know them for what they were" (77). Roy writes "He lived in a caravan" (78). In another example, she writes "Baby Kochamma wrote for her father: My dearest Papa, [...] But Koh-i-noor appears to be unhappy and homesick" (13). It is a name of a girl. The researcher believes that this is a sign of diasporic communities in India, especially in Kerala. This belongs to a Parsi community, because this is a Persian word.

This story is about the real Indian society, written by one of its own nationals. Roy defines the book as an inextricable mix of experience and imagination. Hybridity is one of the most important features in the novel. The migration forms the hybrid identities. When the migrants interact with the local population, hybridity takes place. It is the most central term in the novel. Every human being has own personal identity that relies on a sense of who he is in relation to the larger community, the nation. In The Location of Culture, Bhabha claims that all cultural statements and systems are constructed in a space that is called the "Third Space of Enunciation" (38). Cultural identity always emerges in this contradictory and ambivalent space, which for Bhabha makes the claim to a hierarchical purity of cultural untenable. For him, the recognition of this ambivalent space of cultural identity may help us to overcome the exoticism of cultural diversity in favour of the recognition of an empowering hybridity within which cultural difference may operate.

There are biological, cultural and linguistic hybridity. In the novel, Sophi Mol is the only real hybrid, because her father Chacko is an Indian and her mother, the Christian Margaret. Baby Kochamma speaks about the twins "...they are Half-Hindu Hybrids ..."s (126). This is biological hybridity. Cultural hybridity is as a contact and intermixture between different cultural groups often taken place in the historical context of colonization. Father's Ammu is a Hindu and her mother is a Syrian Christian like the rest of the Ipe family. The twins, Rahel and Estha, show the cultural hybridity. Their mother is Ammu and their father is Babu. They have not seen each other because Estha was sent away as a child to lives with Babu in Assam. Chacko, Ammu's brother, shows another cultural hybridity as Marxist, a man of masses, but he believes his privilege as a high caste male. $\mathrm{He}$ is educated at Oxford. But he has sexual relation with the lower-caste women. But when he finds the relationship between Ammu and Velutha he neglects his modern beliefs and returns to the ancient regime of caste system. This shows a paradox in his behavior. This is hybrid behavior. Sophi Mol, Chacko' daughter, is trained in English culture. This sentence "...a white child's body..." (119) being English Sophi.

TGST is full of hybridity in terms of language too. "Linguistic examples include pidgin and creole languages, which are local versions of a language brought by colonizers" [13]. We could find the following samples for the linguistic hybridity: Arundhati Roy is an Indian writer, but she writes her novel in English. We can see frequently Malayalam words, poems or verses of songs. The writer tries to translate some of these words. We can give this example of these songs: "A song from the Onamboatrace filled the factory. 'Thaiythaiythakathaiythaiythome! Enda da korangacha, chandiitharathenjadu? (Hey Mr. Monkey man, why's your bum so red?" (94). Sometimes the characters do not speak English and cannot understand the other characters. One of these characters is Kochu Maria. This is showing in this sentence of the novel: "Estha would rise from the dead, stand on his bed and say, 'Et tu? Kochu Maria? - Then fall Estha!' and die again" (40). Kochu Maria was sure that Ettu was an obscenity in English and was waiting for a suitable opportunity to complain about Estha to Mammachi. Sometimes the characters speak English, but do not know what they are saying. They have learned to pronounce a word, but it has no meaning for them. A good example for this situation is when Comrade Pillai's son, Lenin, cites Shakespeare: "lend me yawYERS" (ibid 129). Sometimes words are written as the twins imagine them: "They had to form the words properly, and be particularly careful about their pronunciation. Prer NUN sea aysun" [14]. This shows they play with English words easily. Sophi Mol is a word which is composed of two parts; Sophi and Mol. This word is a mixture of English and Malayalam that indicates Kerala's multiple local linguistic cross-currents. Roy uses words from India's state language into her English novel. He accepts the role of interpreter for non-Malayalam-speaking readers when she explains the words: "In Malayalam, Mol is Little Girl and Mon is Little Boy" (29). This is an example for hybridity in the novel. Sometimes Roy protects the power relations of this cultural mediation, when she refuses to explain: "Estha and Rahel couldn't call [Chacko] Chacken because when they did, he called them Chetan and Cheduthi. If they called him Ammavan he called them Appoi and Ammai [...] so they called him Chacko" (ibid 18). Roy tries to emphasize in names and naming for constructing meaning and identity. This quotation estranges her "non-Malayalam readers" and shows that "cultural differences cannot always be easily translated or explained" [15].

Migration and diaspora are concerns of postcolonialism. Roy criticizes traditional forms of cultural practice, including patriarchal societies, or religious and ethic groupings in her book with regard to feminism and nationalism. With regard to diasporic literature, a whole new set of questions arises. 
The diasporic writers we are looking at often describe very new problems and circumstances. They often talk about how enabling it can be for women to be in a different kind of community. This different kind of community can be the complex community of Kerala. Roy shows how the everyday is lived and is loaded with complexity. It shows how grand scale national politics cannot be understood without that micro-vision. The migration of Syrian Christians is significant migration in the novel. Roy remarks the history of Syrian Christian.

Four migrations are pointed in $T G S T$. The first refers to Syrian-Christian community to Kerala. Kerala's population were Syrian Christians, who believed that they were descendants of the one hundred Brahmins whom Saint Thomas the Apostle converted to Christianity when he travelled east after Resurrection. The second refers to Chacko's migration to Britain. The third refers to Rahel's migration to America. The fourth refers to Father Mulligan's migration to India. He is an Irish priest who comes to Kerala for studying Hinduism. And finally he converts to Hinduism. The present researcher believes that it may constitute hybrid and diasporic identity in the result of these migrations.

The character of Rahel, which is similar in many aspects to Arundhati's eventful life, deals, briefly, with the diasporic existence. Her TGST is semi-autobiographical and mixes her childhood experiences in Aymanam with a postcolonial scrutiny of history and relationships. Traditionally, the diaspora has been represented as a division, some kind of a loss, a draining, and eternal longing for what could be and was elsewhere, the home somewhere else, retained in the imagination, preserved like Arundhati Roy's famous pickling factory pickling exotic pickles.

Communism Party was successful in Kerala. Chacko had no really complete explanation for why the Communist Party was so much more successful in Kerala than it had been almost anywhere else in India, except perhaps in Bengal. Although Roy tries to answer to this success, the present researcher believes that because Kerala's community was complex and diasporic community. And according to Communism, the people must be equal to each other. Thus Communism was more successful and it had followers in this region.

The present researcher believes that there are some issues of diasporic language in complex Indian society. We can these diasporic issues in TGST. When the Moguls invaded Iran and the Iranians converted them into ambassadors of the Iranian language. They made Persian or Parsi their court language in India. Parsi was the language of the court of many of the Indian kings till the British banned its use, after occupying India in the eighteenth century. Roy uses four diasporic words which are originated from Persian and then they come in English. We can see these words in the following sentences: when Roy writes "His family were once-wealthy zamindars who had migrated to Calcutta from East Bengal after partition" (TGST 19), she speaks about Ammu's husband. The word "zamindars" in this sentence shows diasporic feature in TGST. Roy writes "They did [...] caught in the bazaar - branded them so that everybody would know them for what they were" (77). Roy writes "He lived in a caravan" (78). In another example, she writes "Baby Kochamma wrote for her father: My dearest Papa, [...] But Koh-i-noor appears to be unhappy and homesick" (13). As Roy described about the name "Koh-i-noor" belongs to a Muslim person. It is a name of a girl. The researcher believes that this is a sign of diasporic communities in India, especially in Kerala. This belongs to Pharsi community, because this is a Persian word.

\section{Conclusion}

This article studied Arundhati Roy's TGST. Roy is an Indian writer and activist in women's studies. The plot of the novel takes place in Ayemenem, in Kerala, an Indian state. Kerala is a small India, because it is like India for having a complex and multicultural society. The novel can be a model for postcolonial research. India is a country which was colonized by British Empire at the end of the sixteenth century. This land had important benefit for Britain. This colonization affected Indian society, culture, and literature. Therefore, there has been an attempt to discuss the history of colonization, colonization in India and the effect of colonization in Indian culture, and literature. Postcolonialism is a state after the formal end of colonialism. The aspects of postcolonialism may be in history, literature and politics. Postcolonialism affected both the countries that were colonized and the former colonial powers. It is necessary to analyze some postcolonial concepts such as the relationship between the role of women and postcolonial literature, history, Saidian Orientalism, diaspora and hybridity. They are important in the history of human life. Diaspora has taken place in various layers of Indian history. This is a basic issue on which Bhabha's works. Diaspora refers to the movement of a group of a people from a land to another land. Diaspora has mostly taken place during migration and transition. This is an important issue in this novel. There are many races in the world. These races have different cultures and ideas. Hybridity is created by mixing two races. The concept of hybridity is a central term to postcolonial theory. It is a significant issue in the novel. Another issue is the role of women in Indian society, because there are several female characters, such as Ammu, Rahel, and so on in TGST. The novel challenged static notions of identity, specifically the construction of postcolonial women. Women had an important role in postcolonial theory. Because the family becomes the symbol of anti-colonial movement and it indicates inner space in colonialism. Roy as a hybrid diasporic woman tried to relate to gender and caste among other social concerns. She tried to express her own experience in her own voice.

\section{References}

[1] Ashcroft, Bill et al. The Postcolonial Studies Reader. New York: Routledge, 2006. 
[2] Bhabha, Homi K. Nation \& Narration. New York: Routledge, 2000 .

[3] The Location of Culture. New York: Routledge, 1994.

[4] Loomba, Ania. Colonialism/Postcolonialism. London: Routledge, 1998.

[5] Loomba, Ania. Postcolonial Studies. London and Durham: Duke University Press, 2000.

[6] Loomba, Ania et al. Postcolonial Studies and Beyond. London and Durham: Duke University Press, 2005.

[7] Mashale, Dr. Ashok. "The Postcolonial Perspectives in Indian English Novels”. Indian Stream Research Journal. 2011: 32-3.

[8] McLeod, John. Beginning Postcolonialism. Manchester: Manchester University Press, 2000.
[9] Roy, Arundhati. The God of Small Things. Islamabad: Harpernnial, 1998.

[10] Said, Edward. Orientalism. London: Penguin Books, 2003.

[11] Said W, Edward. Culture and Imperialism. New York: Vintage Books, 1993.

[12] Tickell, Alex. Arundhati Roy's The God of Small Things. New York: Routledge, 2007.

[13] Wisker, Gina. Key Concepts in Postcolonial Literature. London: Palgrave, 2007.

[14] Woodward Kath, Understanding Identity. Great Britain: Oxford University Press, 2002.

[15] Young J. C, Robert. Colonial Desire. New York: Routledge, 2005. 